\title{
TÖRTÉNELEMTANÍTÁS EGYKOR ÉS MA: A TÖRTÉNELEMTANÍTÁS KIHÍVÁSAI A XXI. SZÁZADBAN
}

\author{
GORTVA JÁNOS \\ Eszterházy Károly Egyetem Gyakorlóiskola \\ Eszterházy Károly Egyetem Neveléstudományi Doktori Iskola
}

\begin{abstract}
A tantárgy-pedagógiák elismertsége általában alacsony, még tudományrendszertani besorolásuk is bizonytalan, ugyanakkor jelentőségük sokkal nagyobb, mint általában gondolják. A tanulmány elején reflektálok azokra a szakirodalmi vitákra, amelyek tantárgy-pedagógiák tudományterületi besorolása körül kialakultak. A további részekben a hazai történelem tantárgy-pedagógiai történetének néhány fontos csomópontját mutatom be. Emellett felvillantom azokat a kihívásokat, amelyek napjainkban a történelemtanítás során megjelennek.
\end{abstract}

\section{Bevezetés}

A történelem tantárgy tanításának hazánkban sok évszázados hagyománya van, azonban a történelem tanításának története, s különösen a tantárgy-pedagógiai egésze már kevésbé feltárt terület. Szerencsére azonban elmondható, hogy az utóbbi években és évtizedekben egyre több olyan írás - közöttük doktori disszertációk és rövidebb-hosszabb tanulmányok éppúgy, mint a helyes gyakorlatokat bemutató, gyakorlatorientált művek - született a témában, amelyek segítik a tantárgy tanításának jobbá, értékesebbé válását. Ebben a tanulmányban az a célom, hogy kettős szempontból járuljak hozzá a történelem tantárgy tantárgy-pedagógiájának fejlődéséhez. Egyfelől az elmélet, másfelől a gyakorlat oldaláról fogok felvillantani néhány kérdést.

Mielőtt azonban a tanulmány szűken vett témájára rátérnék, muszáj felvillantanom egy tudományos vitát is, s részben reflektálni arra. Bárdos Jenő is felhívta a figyelmet arra, hogy a módszertan fontos és hasznos része a tantárgy-pedagógiának, azonban igen parányi része az egészhez képest (Bárdos, 2012 és 2015). Megkerülhetetlen ugyanakkor annak megemlítése is, hogy magának a tantárgy-pedagógiának a megítélése is viták kereszttüzében áll. A Pedagógiai Lexikon 1997-es kiadása például a tantárgy-pedagógia és a módszertan fogalmát lényegében azonosnak tekinti (idézi Kimmel, 2017). Kimmel idézi Katona Andrást, aki viszont éles különbséget tett a szakmódszertan és a tantárgy-pedagógia között 2003-ban (Kimmel, 2017). Katona András később rámutatott arra, hogy a tantárgytörténet 
a neveléstörténetben viszonylag kevéssé kutatott terület, pedig a tantárgy múltjának megismerése nélkül annak jelene sem lesz érthető (Katona, 2010). Bárdos ugyanerre a következtetésre jut, kiemelve azt, hogy a tantárgy-pedagógia fejlettségi fokának egyik mutatója az, hogy mennyire ismerik a tantárgy történetét, korábbi helyes gyakorlatait (Bárdos, 2012 és 2015). Kimmel vitatja Bárdos azon vélekedését, hogy a tantárgy-pedagógia alkalmazott didaktika volna, mert nézete szerint annak egyes területei a szaktudományból erednek, így ő egy a pedagógia és a szaktudomány metszéspontjában álló tudományterületként fogja fel a tantárgy-pedagógiát (Kimmel, 2017). Érzésem szerint Kimmel ugyanakkor félreérti Bárdost, amikor úgy fogalmaz, hogy előbbi pusztán alkalmazott didaktikának tekinti a tantárgy-pedagógiát és alárendeli azt a didaktikának. Bárdos ugyanis így szól: „Ugyanakkor minden tantárgy-pedagógia integrált multidiszciplina, mely alapfokú polihisztorságot igényel, melynek az árát, egy ilyesféle tudást, kezdettöl fogva meg kellett fizetnie. [...] A pedagóguson, akár mindennapi, akár tudományos munkáiban, az összefonódó tudományágak mindegyikét külön-külön is számonkérik - ezért feltétel a polihisztorság” (Bárdos 2012 és 2015). Így tehát, bár a pedagógia, még pontosabban a didaktika felől közelít a tantárgy-pedagógiához, Bárdos maga is kijelenti, hogy a tantárgy-pedagógia a tudományterületek metszéspontjában áll, s egyes részei nyilvánvalóan a szaktudományból erednek. Szó sincs tehát arról, hogy pusztán alkalmazott didaktikának tekintené a tantárgypedagógiát. Ezt erősíti Bárdos 1997-ben megjelent tanulmánya (Bárdos, 1997) és a 2000-ben megjelent monográfiájának 8. ábrája is (Bárdos, 2000, 32.), amelyben a tantárgy-pedagógiát egyértelműen a tantárgyi tudományból eredő, de a pedagógia és a pszichológia tudományával is metszetet alkotó tudományterületként ábrázolja, 1997-es megfogalmazása szerint nem is határ, hanem határokon túli területként (Bárdos, 1997, 15.). Bárhogy tekintünk is a tantárgy-pedagógiák tudományrendszertani helyére, egy bizonyos: A tantárgy-pedagógiákkal, s ennek részeként a tantárgyak történetével foglalkozni kell, mert ahogyan arra Pukánszky Béla is rámutatott, a tantárgy-pedagógia alapvetően háttérbe szorult a pedagógusképzésben (Pukánszky, 2015), így annak fontosságára célszerü felhívni a figyelmet. Ez adja ennek a tanulmánynak az egyik aktualitását.

A továbbiakban - részben Bárdos és Katona logikáját is követve - ez a tanulmány lényegében két nagyon jelentős részére világít rá a történelem tantárgy-pedagógiájának. Egyfelől tisztelgés kíván lenni az egri kötődésű Balassa Brunó előtt, aki 1921-ben, 100 esztendővel ezelőtt kezdte meg tanári működését Egerben és elsőként írta meg a történelem tanításának történetét Magyarországon, másfelől viszont reflektálni kíván mindazokra a kihívásokra, amelyek a gyakorlatban érik a történelemtanárokat a XXI. század első negyedének vége felé. Ilyen módon egyszerre érinti a történelem tanításának történetét, s annak jelenét, a szűken vett módszertan kérdéseit is. Egyszerre jelenik meg tehát benne a szinkrón és a diakrón szemlélet, ahogyan arra a címben is utalok. Természetes ugyanakkor, hogy a történeti 
részben meg kell haladni Balassa Brunó munkájának időhatárait, hiszen ő maga sem jutott el saját koráig, s azóta is eltelt közel egy évszázad. Szólni kell tehát a tantárgy tanításának közelmúltjáról is ahhoz, hogy a jelenéről beszélhessünk.

\section{Balassa Brunó, az első történelem-tantárgypedagógus hazánkban}

Mielőtt Balassa Brunó művének bemutatásába kezdek, röviden fel kell vázolnom a szerző életútjának legfőbb állomásait. Meglehetősen kevés feldolgozás áll rendelkezésre ehhez, jórészt csupán lexikonok szócikkeiben lelhető fel a neve, mégis érdemes néhány életrajzi adatot megismerni róla. A magyar életrajzi lexikon adatai szerint 1896-ban született Székesfehérvárott Aschenbrenner István néven. 1912-ben lépett be a ciszterci rendbe. (Magyar életrajzi lexikon, 2001). Középiskoláit Székesfehérvárott és Egerben végezte, ezt követően Innsbruckban folytatott egyetemi tanulmányokat, majd visszatért Egerbe, ahol 1921 és 1925 között a rend gimnáziumi tanáraként tevékenykedett. Bölcsészdoktori értekezését 1929-ben védte meg A történettanítás múltja hazánkban címmel. Elismertségét jól mutatja, hogy a Bernardinum ${ }^{1}$ tanára, majd igazgatója és a Szent István Akadémia tagja is lett. A Vallás- és Közoktatásügyi Minisztériumban a népiskolákkal foglalkozó osztályvezető is volt. A szerzetesrendek felszámolását követően nyugdíjazásáig vállalati előkalkulátorként dolgozott. 1979-ben Budapesten hunyt el (Kozák, 2013). A magyar és egyetemes neveléstörténet kutatása mellett nyelvpedagógusként is kiváló volt. A latintanítás története címü monográfiájával a nyelvpedagógiában is maradandót alkotott (Bárdos, 2005). Láthatjuk tehát, hogy Balassa Brunó egyszerre volt kiváló neveléstörténész, nyelvpedagógus, tanár és szerzetes. Munkássága sokrétű, s több tekintetben úttörő volt.

\section{A történelemtanitás múltjának elsö magyar összefoglalója}

Balassa Brunó már munkájának bevezetőjében is egyértelművé tette, hogy miben is áll valójában a művének újszerűsége. Szavai szerint: „Ezzel az irással jórészt töretlen ugar került szántás alá, mert a történettanitás iskolás múltja sem nálunk, sem külföldön a legújabb idökig nem találta meg a maga munkásait." (Balassa, 1929). Egyértelművé teszi tehát, hogy vizsgálódása a tantárgy tanításának történetére fókuszál és ez meglehetősen újszerủ akkoriban. Kifejezetten modern felfogást tükröz és ma is helytálló Balassának az a megállapítása, amely szerint a kultúra az egyik kulcs a múlt megismeréséhez. Kiemeli, hogy a mondák vagy éppen a klasszikus művekben található államelméleti és jogi ismeretek vizsgálata, értelmezése rendkívül fontos lett volna a történelemszemlélet alakításában, ez azonban

1 A magyar ciszterci rend tanulmányi háza. 
hosszú évszázadokig elmaradt (Balassa, 1929). Voltaképp, kimondatlanul is a forráselemzés fontosságára hívta fel a figyelmet.

Maga a mủ három, önmagában is fontos szakaszra oszlik. A szerző először áttekinti a történelem tanításának általános fejlődését. Beszél a történelem tanításának középkori gyökereiről, a humanisták immár iskolarendszerü történelemoktatásától egészen a XVIII. századig. Röviden szól Melanchton és Sleidanus tankönyveinek jellegéről, s a felsőfokú oktatás, illetve a középfokú oktatás történelemtanítási szemléletének különbségéről. Szól arról - s ebben is modern gondolatok tükröződnek - hogy a tudományos ismeretanyag megfelelően átgondolt válogatása, pedagógiai szempontú átdolgozása nélkül elképzelhetetlen a sikeres iskolai oktatás. Nézetei szerint ebben az első lépést a pietisták tették meg akkor, amikor gyakorlati és nevelő célzatú ismereteket kerestek a történelmi ismeretanyagban és ezek tanítását állították a fókuszba. Kifejezetten érdekes mai szemmel olvasva az, hogy már a pietisták is felhívták a figyelmet arra, hogy a tanulók figyelmének az óra elején való fókuszálása az óra sikerének kulcsa (Balassa, 1929, 28). Nincs másról szó, mint a mai értelemben vett motivációról és az órai célkitűzésről, bár természetesen ezek a didaktikai szakkifejezések itt még nem tűnnek fel. Ennek a fejezetnek az igazi erényét abban látom, hogy a történettanítás történetét úgy mutatja be, hogy az adott korszakok ismeretanyagából, illetve tankönyveinek elemzéséből indul ki. Emellett részletesen szól a tanítás - egyébként jórészt frontális - éppúgy, mint a számonkérés rendszeréről. Azt mondhatjuk tehát, hogy a tananyagot, a taneszközöket, a tanítás módszereit és a mérést, értékelést is vizsgálja, annak történetét is bemutatja. Lényegében mindazon elemek megtalálhatók benne, amelyek egy mai tantárgy-pedagógiai áttekintéstől is elvárhatók.

Balassa munkájának második egységét a történettanítás hazai képének Ratio Educationis előtti bemutatása adja. Ezt a szakaszt öt egységre bontja, bemutatja a hazai protestáns, a jezsuita, a kegyesrendi, valamint az egyéb katolikus iskolákban. E tanulmány célja nem az, hogy részletesen szóljak ezekről, így az előzőhöz hasonlóan itt is csak az általános jegyeket mutatom be. A szerző itt is azt a logikát követi, hogy az iskolai tanterveket, a tanítási módszereket és ahol módjában áll, a tankönyveket, taneszközöket vizsgálja. Áttekintésében olyan nagyhatású tantárgy-pedagógusok munkássága is feltűnik, mint például Bél Mátyásé. A módszerek tekintetében pedig a dramatikus feldolgozás éppúgy szóba kerül, mint a tanári előadás, vagy éppen a kérdőívek kitöltése, tulajdonképpen a mai projektmunkák egyik lehetséges előképe. E módszerek és tantervek részletes bemutatása akár önálló tanulmányok egész sorát is adhatnák, így ettől most eltekintek. Arra azonban fel kell hívni minden tantárgy-pedagógia iránt érdeklődő figyelmét, hogy ezek széleskörű leltára Balassa munkájában fellelhető.

A harmadik, egyben zárórészt a Ratio Educationis adja. Nyilvánvaló rokonszenvet érez a Ratio azon gondolatával, hogy a magyar történelmet helyezi a középpontba és 
a felvilágosodás különféle irányzatait összegzi, ugyanakkor módszertani szempontból például kiemeli a rendszeres ismétlések hiányát mint hiányosságot. Meg kell jegyezni ugyanakkor, hogy a - mai szóhasználattal - tantárgyi belső koncentráció jelenségére utal. Azaz arra, hogy a tanár az előadások során többszörösen utal és felidézi a korábban tanultakat. Többek között ez is olyan módszertani szempontú elemzés, ami hasznos olvasmánnyá teszi Balassa művét. Ebben a szakaszban is szó esik a taneszközökről, még pontosabban a tankönyvek hiánya okozta problémáról, ugyanis a Ratio Educationis úgy lépett életbe, hogy a megfelelő tankönyvek még nem készültek el. Elemzése érdekes és hasznos, de ahogyan a korábbiakban, itt sem térek ki annak részletes bemutatására.

Balassa művének tudományos értékét az R.N. monogram mögött rejtőző recenzens is kiemelte a Katolikus Szemle 1932. évi 11. számában, rámutatva arra, hogy a műben igen széles ismeretanyag, tárgyi tudás és pedagógiai szempontok sokasága ötvöződik. Kritikája, amely a munka nyelvezetére vonatkozik, nem veszi figyelembe, hogy doktori értekezésról van szó, tehát a nyelvi megformáltság ehhez igazodott. Hasonlóan pozitívan ír Miskolczy István is a Századok 1929-30-as számában megjelent kritikájában, ez tehát azt mutatja, hogy a kortársak körében sem maradt visszhangtalan a munka. Néhány módszertani megállapítása ma is időszerü és a mai történelem-tantárgypedagógusok figyelmét is felhívja arra, hogy a megoldások keresése közben érdemes a régi, akár évszázadokkal korábbi tantervek, tankönyvek módszertani gondolataira is figyelnünk.

\section{Történelemtanitásunk néhány csomópontja 1806-tól a rendszerváltásig}

Egy ilyen tanulmányban nem vállalkozhattam arra, hogy a történelemtanításunk teljes múltját feltárjam, az nyilvánvalóan egy nagymonográfia terjedelmi kereteit kívánná meg. Néhány csomópont és érdekesség kiemelése azonban mindenképpen fontos mielőtt napjaink új kihívásaira rátérnénk. A válogatás természetesen szubjektív, mások mást emelnének ki a több, mint 200 év eseményeiből, mégis fontosnak tartom, hogy ezt a rövid áttekintést elkészítsem. Ott kell folytatnunk, ahol Balassa befejezte, 1806-tal, azaz a második Ratio Educationissal. A második Ratio szemléletmódban hozott újat, mégpedig olyat, ami napjainkig meghatározó: az oksági viszonyok feltárásának fontosságát (Gőzsy-Dévényi, 2011). Ez a szemléletmód ma is jelen van a történelemtanításban, ezért fontos csomópontnak tartom. A következő nagy csomópont a valódi tankönyvek megjelenése. A dualizmus koráig a tankönyvek valójában kézikönyvek voltak, amelyeket az oktatásban is használtak. 1883-tól azonban megkezdődött az állami tankönyvbírálat és engedélyezés, az 1879-es tanterv országos érvényủ lett, s ennek alapján kezdtek készülni a tankönyvek (Gőzsy-Dévényi, 2011). Ez tehát egy minőségi ugrás, amit alapvető fontosságúnak tartok. Mangold Lajos tankönyvéhez például forrásgyűjtemény is tartozott (Gőzsy-Dévényi, 2011), tehát lényegében már a XIX. században adott volt a tanárok számára a forrásközpontú történelemtanítás lehetősége. A következő minőségi ugrás 
a Horthy-korszak. Albert Gábor kutatásai alapján ugyanis kijelenthető, hogy az 1920-as évekre a tankönyvírás professzióvá vált. Megjelentek a metodikai értelemben vett modern tankönyvek (Albert, 2015, 97.), ugyanakkor a dualizmus korának tankönyvei még sokáig rendkívül népszerűek voltak, elsősorban a tanárok ragaszkodása miatt (Albert, 2015, 98).

A második világháború utáni években, a koalíciós időszakban a történelemtanításon belül fontos szerepet kapott az állampolgári nevelés és egy viszonylagosan nagy tanári szabadságot látunk a tantervekben (Gőzsy-Dévényi, 2011). Mindennek a valódi kibontakozását azonban nem követhetjük nyomon, hiszen hamarosan elkövetkeztek a pártállami idők, amelyek újabb fordulatot jelentettek.

A pártállami időszak történetírásának változásairól ebben a tanulmányban nem írok, viszont feltétlenül látni kell, hogy maga a történetírás is alapjaiban változott meg, ez azonban historiográfiai terület, így végső soron a tantervekben és a tankönyvekben is megjelennek a hatásai. Az 1950-es években a marxista ideológia kizárólagossága érvényesült a tantervekben és a tankönyvekben, de az 1960-as évek könyvein már érezhető a változás, hiszen Sztálin és Rákosi szerepeltetése háttérbe szorult. Az 1950-es évek könyveiben gyakorlatilag nem volt didaktikai apparátus. Az 1970-es évek tankönyvei viszont már jelentős előrelépést mutattak, forráselemző leckékkel, többféle forrástípust megjelenítve kerültek a tanulók elé (Gőzsy-Dévényi, 2011).

\section{A rendszerváltást követö évek nébány csomópontja a történelemtanításban}

Az 1995-ös és a 2003-es NAT, illetve a szélesedő tankönyvkínálat mind tartalmi, mind módszertani szempontból magában foglalta volna a módszertani megújulás lehetőségét, ez azonban elmaradt. Egy 2004-es vizsgálat azt igazolta, hogy a tanárok ragaszkodnak a régi módszerekhez és dominál a frontális munka, illetve a tanári magyarázat, míg a forrásfeldolgozás háttérbe szorul (Kaposi, 2020, 58). Ez önmagában is azt mutatja meg, hogy az 1990-es években nem történt jelentős előrelépés, a korábbi évekhez hasonlóan alapvetően csekély volt a módszertani változatosság az órákon. Azonban 2005-ben egy olyan paradigmaváltás következett, ami alapjaiban változtatta meg mindezt.

Egy közel tíz esztendős fejlesztési folyamat végén, 2005-ben bevezették a kétszintű érettségi rendszerét. A vizsgafejlesztést sok vita kísérte, az új rendszer bevezetését sokáig ellenezték is, azonban végül gyors és sikeres bevezetésre került sor. Az új vizsgarendszer nagy problémaérzékenységet és sokrétű ismeretanyagot várt el a vizsgázóktól (Kaposi, 2020, 66-68). Az új típusú érettségi vizsga bevezetése és működése megkívánta a pedagógusok módszertani megújulását, a forrásközpontúság és az eseményeket alakító tényezők vizsgálatának előtérbe helyezését. Ezt pedig új, forrásközpontú tankönyvcsaládok is segítették.

A NAT 2012-es újabb változásai részben tartalmi, részben arányváltozásokat eredményeztek az érettségi rendszerben, amely változások 2017 óta vannak érvényben (Kaposi, 2020, 89). 


\section{Napjaink kibívásai}

Az oktatás egésze jelentős kihívások előtt áll a digitális paradigmaváltás következtében, ez természetesen a történelemtanítást sem kerülte el. A 2020-as pandémia világossá tette, hogy jelentős módszertani változásokra van szükség a történelemtanítás vonatkozásában is. Egyértelmủ, hogy a játékosításnak, valamint a digitális platformok használatának egyre nagyobb jelentősége lesz a jövőben, így módszertani szempontból erre kell felkészíteni a tanárjelölteket, illetve a pedagógus-továbbképzések keretében a pályán lévő kollégákat is. Megkerülhetetlen ugyanakkor a kérdés, hogy a NAT2020 milyen mértékủ változásokat fog indukálni a történelemtanításban. A jövő idő használata indokolt, hiszen csak a tartalmi szabályozót ismerjük, a taneszközöket és a kimeneti követelményeket még nem.

A NAT2020 követelményeinek megfelelő érettségi vizsgarendszer és vizsgakövetelmények még nem ismertek, így a tartalmi elemek sem. A tankönyvek is csak egy-egy évfolyamra készültek el, s még csak nem is minden képzéstípusra. A hat- és nyolcévfolyamos gimnáziumi képzés esetében például nem áll rendelkezésre a NAT2020-al kompatibilis tankönyv, így az ebben a képzéstípusban tanuló diákok felkészítése a tanárok részéről minden eddiginél nagyobb módszertani és szakmai erőfeszítést igényel.

Az új NAT előirásai sok szempontból kedvező előrelépést jelentenek, hiszen például újra önálló tantárggyá tették az állampolgári ismereteket és jelentősen átstrukturálták a tananyagot, elméletben pedig nagyobb teret kaphatna például a levéltári kutatás. Ugyanakkor az óraszámok és a bizonytalan kimenet egyelőre nem teszik lehetővé a ténylegesen jelentős változásokat. Bízni kell azonban abban, hogy olyan új tankönyvek és olyan érettségi vizsgakövetelmények készülnek hamarosan, amelyek lehetővé teszik a nagyszámú digitális adatbázison és a digitális technika adta lehetőségeken nyugvó modern, forrásközpontú, tanulói aktivitáson alapuló történelemtanítást. Az elmúlt években számos olyan publikáció látott napvilágot, amelyek a történelemtanítás digitalizációjával kapcsolatos lehetőségeket villantottak fel (lásd például Érsek, 2020; Gortva, 2017 és 2016), illetve az Okostankönyvprojekt például újabb digitális eszközöket adott a tanárok kezébe. Bízni kell abban, hogy a szakma - a korábbi évekhez hasonlóan - most is meghallja az idők szavát és a történelemtanítás modern, XXI. századi lehetőségeit maximálisan kihasználva válaszol a kihívásokra.

\section{Összegzés}

A tanulmányban bemutattam a tantárgy-pedagógiák tudománymódszertani besorolásával kapcsolatos viták egyik aspektusát, amely véleményem szerint azért fontos, mert fel kell hívni a figyelmet arra, hogy a megfelelően kidolgozott tantárgy-pedagógia és ennek részeként a megfelelő tanításmódszertan egyfelől rendkívül fontos, másfelől pedig a sikeres 
oktató-nevelő munka egyik feltétele ennek megismertetése a pedagógusokkal. Emellett a történelem tantárgy-pedagógiájának történetéből is készítettem egy rövid áttekintést, kiemelt figyelmet szentelve Balassa Brunó viszonylag elfeledett munkásságára. Ennek aktualitása egyrészt abban áll, hogy Balassa Brunó 1921-ben kezdte meg tanári munkáját Egerben, tehát egyfajta megemlékezés mindenképpen szükséges, másrészt szándékomban állt annak bemutatása, hogy az 1929-ben megjelent tantárgytörténeti munkájában számos olyan gondolat megjelenik, amely ma is fontos, ma is érvényes üzenettel bír. Az írás utolsó szakaszában pedig felvillantottam azokat a kihívásokat, amelyek elött a ma és a közeljövő történelemtanítása áll. Természetesen a terjedelmi korlátok nem teszik lehetővé a problémafelvetéseken túli, konkrét módszertani megoldási javaslatok felvázolását, de talán felhívják a figyelmet az irányokra és elindítanak egy tudományos párbeszédet, illetve hozzájárulnak a már megkezdett fejlesztési, kutatási munkák folytatásához. Rövid tanulmányom célja tehát az, hogy felhívjam a figyelmet a tantárgy-pedagógiánk múltjában rejlő eredményekre és a jövőjében lévő kihívásokra.

\section{Felhasznált irodalom:}

Albert, G. (2015). Tankönyvpiac, tankönyvhasználat, tankönyvrevizió: Mozzanatok a klebelsbergi korszak történelemtankönyv-történeti és iskolatörténeti kutatásaiból. Habilitációs értekezés. Eger: Eszterházy Károly Főiskola Neveléstudományi Doktori Iskola. doi:10.15773/EKF.HABIL.2015.003

Arcanum kézikönyvtár. (dátum nélk.). Forrás: Magyar életrajzi lexikon B: https://www. arcanum.hu/hu/online-kiadvanyok/Lexikonok-magyar-eletrajzi-lexikon-7428D/b74700/balassa-bruno-istvan-1912-ig-aschenbrenner-7479C/

Balassa, B. (1929). A történettanitás múltja hazánkban. Budapest. Forrás: https://mtda.hu/ books/balassa_bruno_a_tortenettanitas_multja_hazankban.pdf

Bárdos, J. (1997). A nyelvpedagógiai fejlődése és tudatosulása. Magyar Pedagógia, 3-17. Forrás: http://www.magyarpedagogia.hu/document/Bardos_MP971.pdf

Bárdos, J. (2000). Az idegen nyelvek tanitásának elméleti alapjai és gyakorlata. Budapest: Nemzeti Tankönyvkiadó. Forrás: http://mek.oszk.hu/18000/18010/18010.pdf

Bárdos, J. (2005). Élö nyelvtanitás-történet. Budapest: Nemzeti Tankönyvkiadó. Forrás: http://mek.oszk.hu/18000/18009/18009.pdf

Bárdos, J. (2012). A tantárgy-pedagógiák szerkezete, megitélésük kritériumai. Magyar Pedagógia, 61-75. Forrás: http://misc.bibl.u-szeged.hu/14214/1/mp_2012_002_6539_ 061-075.pdf 
Bárdos, J. (2015). A tantárgy-pedagógiák anatómiája. In Környezeti nevelés és tudatformálás (old.: 53-66). Eger: EKF, Líceum Kiadó.

Érsek, A. (2020). A kritikai gondolkodás szerepe és ismérvei a történelemtanításban: Egy kvalitatív kutatás összegzése. Történelemtanitás Online történelemdidaktikai folyóirat, 1-17. Forrás: http://www.folyoirat.tortenelemtanitas.hu/2020/05/ersek-attila-a-kritikaigondolkodas-szerepe-es-ismervei-a-tortenelemtanitasban-11-01-05/

Gortva, J. (2016). A helytörténeti kutatás és az online gyűjtemények helye és szerepe a történelemoktatásban Pásztó példáján keresztül. Módszertani közlemények, 2, 32-38. Forrás: http://acta.bibl.u-szeged.hu/46340/1/modszertani_056_002_032-038.pdf

Gortva, J. (2017). A kompetenciafejlesztés lehetőségei a történelemoktatásban, különös tekintettel a helytörténet tanítására. Magiszter, 1, 30-35. Forrás: http://padi.psiedu. ubbcluj.ro/wp-content/uploads/Magiszter_2017_1_pp_30-35.pdf

Gőzsy, Z., \& Dévényi, A. (2011). A történelem tanitásának tartalmi és módszertani változásai. Pécs: Pécsi Tudományegyetem. Forrás: http://janus.ttk.pte.hu/tamop/tan anyagok/tort_tan_valt/index.html

Kaposi, J. (2020). Közelitések a történelemtanitás elméletéhez és gyakorlatához. Budapest: Pázmány Péter Katolikus Egyetem. Forrás: http://kaposijozsef.hu/wp-content/uploads/ 2020/08/Kozelitesek_kotet_egyben_internetre-PDF-1.pdf

Katona, A. (2010). Tantárgytörténet: a neveléstörténet mostohagyermeke. Történelemtanitás Online történelemdidaktikai folyóirat. Forrás: https://www.folyoirat.tortenelemtanitas. hu/2010/02/katona-andras-tantargytortenet-a-nevelestortenet-mostohagyermeke/

Kimmel, M. (2017). A tantárgypedagógiák helye és szerepe a pedagógusképzésben. Pedagógusképzés, 4-22. doi:https://doi.org/10.37205/TEL-hun.2017.1-4.01

Kozák, P. (2013). Balassa Brunó. Névpont.hu. Forrás: https://www.nevpont.hu/palyakep/ balassa-bruno-istvan-8df70

Miskolczy, I. (1929-1930). Balassa Brunó: A történettanítás múltja hazánkban. Századok, 429-431.

Pukánszky, B. (2015). A tanárképzés paradigmái és szerkezeti-tartalmi változásai Magyarországon. Forrás: http://www.pukanszky.hu/postbologna.pdf

R., N. (1932). Balassa Brunó: 1. A történettanítás multja hazánkban 2. A latin tanítás története. Katolikus Szemle, 395-397. 